\title{
SPRY4 Intronic Transcript 1
}

National Cancer Institute

\section{Source}

National Cancer Institute. SPRY4 Intronic Transcript 1. NCI Thesaurus. Code C98181.

SPRY4 intronic transcript 1 ( 700 bases) is encoded by the human SPRY4-IT1 gene. This oligoribonucleotide may play a role in melanoma development. 